\title{
Exploring the Journey to Services
}

\author{
Veronica Martinez *, Andy Neely, Chander Velu \\ vm338@cam.ac.uk \\ Cambridge Service Alliance, Institute for Manufacturing \\ Department of Engineering, University of Cambridge, UK
}

Stewart Leinster-Evans

BAE Systems plc.

Dav Bisessar

International Business Machines Corporation

\section{${ }^{*}$ Corresponding author}

Keywords: service journey, servitization, service transitions

\begin{abstract}
Firms are increasingly providing services to complement their product offerings. The vast majority of studies on the service journey, also known as servitization or service transition, examine the challenges and enablers of the process of change through cases studies. Investigations that provide an indepth longitudinal analysis of the steps involved in the service journey are much rarer. Such a detailed understanding is required in order to appreciate fully how firms can leverage the enablers while overcoming the challenges of servitization. This study investigates what does a service journey look like? It analyzes in some detail the actual service journeys undertaken by three firms in the well-being, engineering and learning sectors. The paper offers four contributions. First, in the change literature, there are two dominant theories: The punctuated equilibrium model and the continuous change model. This study demonstrates that servitization follows a continuous change rather than a punctuated equilibrium. It shows that such continuous change is neither logical nor structured but much more emergent and intuitive in nature. Second, the study provides empirical evidence to support a contingency view of the dominance and sequencing of the different process models of change across the change journey. Third, this research shows the pace of service development and when the coexistence of basic, intermediate and complex services occurs. Finally, it contributes to the literature in the service field by presenting three actual service journeys and the associated seven stages of the service strategy model that organizations should consider when managing their service journeys.
\end{abstract}




\section{Introduction}

Manufacturing firms have increasingly diversified into services (Raddats, Baines, Burton, Story and Zolkiewski, 2016). Globally, over a third of large manufacturing firms offer services, with two out of three in developed countries doing so (Bowen, Siehl and Schneider, 1989; Neely, 2008; Visnjic Kastalli, Van Looy and Neely, 2013; Cusumano, Kahl and Suarez, 2014). Moreover, studies have shown that manufacturers generate, on average, onethird of their revenue from services (Fang, Palmatier and Steenkamp, 2008). Despite the prevalence of services among manufacturing firms, many struggle to manage the transition from product-centric to service-centric business (Bitner, Ostrom and Morgan, 2008; Reinartz and Ulaga, 2008; Spring and Araujo, 2009; Chesbrough, 2010; Ng, Ding and Yip, 2013; Baines, Bigdeli, Bustinza, Shi, Baldwin and Ridgway, 2016). Delivering services requires different operating processes, capabilities, platforms, accountabilities and orchestration of resources that differ from those commonly used to deliver products (Story, Raddats, Burton, Zolkiewski and Baines, 2016; Eloranta and Turunen, 2016). The aim of this paper is to advance our understanding of the journey that firms undertake in their transition to supplement their products with services.

Servitization is the process by which product providers add complementary services to their product proposition (Vanderwe and Rada, 1988; Neely, 2008). Manufacturing firms have increasingly been servitizing as the result of a combination of market pull and technological push in order to focus their business on higher-margin services relative to products and, hence, to create superior competitive advantage (Baines and Lightfoot, 2013; Breitbach and Maglio, 2016). Similarly to the manufacturing industry, the music industry, like other creative industries, had to transition its offerings from selling music in product format to a broader offering of products and services, largely because of the impact of digitalization and the Internet (Parry, Vendrell-Herrero and Bustinza, 2014).

Studies show that information and communication technologies (ICT) facilitate servitization (Eloranta and Turunen, 2016; Story, Raddats, Burton, Zolkiewski and Baines, 2016). For example, ICTs such as video-conferencing, email, the Internet and social media play important roles in enabling service interactions. Breitbach and Maglio (2016) suggest that process-oriented services such as the online meals delivery services provided by Foodora use unstructured and interdependent interactions between actors. Meanwhile, output-oriented services such as the TotalCare services from Rolls-Royce use more structured and independent interactions.

The commercial benefit of offering services is well documented, where the associated revenue could be five or more times the product-related revenue, and profit margins are potentially up to three times higher for services compared to products (Baines and Lightfoot, 2013; Wise and Baumgartner, 1999). However, superior returns for servitization among larger firms are not universal, as the higher costs from the provision of services might not be fully compensated in terms of higher margins (Neely, 2008; Li, Li, Chen and Ma, 2015). Moreover, recent studies have shown that servitization might result in short-term performance sacrifices for longer-term performance benefits (Visnjic, Wiengarten and Neely, 2016). 
Product firms might offer services for various reasons (Cusumano, Kahl and Suarez, 2015). On the one hand, there is the provision of services in mature industries, where the product becomes a commodity and, hence, the provision of services provides a means of differentiation and a source of diversified revenues. On the other hand, the provision of services such as leasing is necessary to persuade customers to buy products that are new to the market based on unknown technologies. Therefore, in this case the service comes first and, hence, substitutes product sales. Some scholars have articulated that servitization is a continuum from basic product-oriented services toward more customized, process-oriented services and ultimately to the provision of solutions (Oliva and Kallengberg, 2003; Tukker, 2004). In such a continuum of servitization, the customer and supplier interface increases from being merely transaction-focused to having more of a relationship orientation, with deep co-engagement from design and development to end-use (Martinez et al., 2010; Gaiardelli, Resta, Martinez, Pinto and Albores, 2014; Eloranta and Turunen, 2016).

One of the key challenges for firms is managing the transition to services. The existing servitization literature has largely discussed the factors associated with the transition, including enablers and challenges, but has not explored the journey that firms undertake in order to servitize (Martinez, Bastl, Kingston and Evans, 2010; Ng, Ding and Yip, 2013). This is surprising given the vast amount of literature on how many product-based industrial firms still struggle to provide services effectively (Bitner, Ostrom and Morgan, 2008; Reinartz and Ulaga, 2008; Neely 2008; Spring and Araujo, 2009). In particular, the service literature has been relatively silent on the service change journey that firms undertake as part of the servitization strategy. Various authors have highlighted the limited attention that has been paid to the process of servitization and, in particular, how such change occurs (Bowen and Schneider, 2014; Kindström and Kowalkowski, 2014; Baines, Bigdeli, Bustinza, Shi, Baldwin and Ridgway, 2016). We explore how the change journey in servitization unfolds within the context of process-based change models (see Van de Ven and Poole, 1995; and Van de Ven and Sun, 2011).

This paper investigates a basic and still relatively unknown enquiry - "What does a service journey look like?" Three case studies, in which three firms have been in transition to supplement their products with services, are discussed in this paper. They describe the service innovations and the transition journeys in the context of complex services. The paper offers four contributions. First, this study demonstrates that servitization follows a continuous change rather than a punctuated equilibrium. It further shows that this continuous change is emergent and intuitive in nature. Second, the study provides empirical evidence to support a contingency view of the dominance and sequencing of the different process models of change across the change journey. Third, this research shows the pace of service development and when the coexistence of basic, intermediate and complex services develops. Fourth, it contributes to the literature in the service field by presenting three actual service journeys and the associated seven stages of the service strategy model that firms need to consider in order to increase the success of their servitization strategy. 


\section{Theoretical background \\ 2.1 Drivers of servitization}

Servitization has been a growing trend for manufacturing firms (Story, Raddats, Burton, Zolkiewski and Baines, 2016; Visnjic, Wiengarten and Neely, 2016). The provision of services can vary for product-based firms. These services could be product-related, such as repair and maintenance. In addition, there are services that support customer use of the products, such as financing, training and optimal use of the product. In doing so, productoriented firms have increasingly shifted their focus from selling products to solutions that focus on positive outcomes for the customer (Roy, Shehab, Tiwari, Rexfelt and Hiort Af Ornäs, 2009; Ng, Ding and Yip, 2013). Studies have classified different types of service in relation to products, namely smoothing, adapting and substituting services (Cusumano et al., 2014). Smoothing services include services that help smooth product sales without altering the underlying product functionality. This includes financing and warranty services. Adapting services are services that expand the functionality of the product or assist customers in using the product in new ways. This could include customization of the product or bundling of the product with other products to provide a bundled proposition. Substituting services are services that replace the purchase of the product for the customer (Paiola, Saccani, Perona and Gebauer, 2013; Settanni, Newnes, Thenent, Parry and Goh, 2014.). These include services such as "pay-peruse", where the customer substitutes buying the product with paying for the service based on usage. Such a conceptualization of services can also be seen through the lens of "value-in-exchange", where the focus is on exchange between parties, or "value-in-use", where the focus is on consuming the service to solve problems and, hence, achieve the desired outcome for the customer (Vargo and Lusch, 2007; Neely, 2008; Gaiardelli, Resta, Martinez, Pinto and Albores, 2014). Recent studies have questioned the productservice continuum - moving from basic product-oriented services toward more customized, process-oriented ones, and ultimately leading to the provision of solutions (see Kindström and Kowalkowski, 2015). The authors argue against the conceptualization of service transition on a uni-dimensional scale across the product-service continuum. They argue that firms must constantly manage the balance between the expansion of customized services to gain differentiation and standardization of the previously customized services into products that are scalable for provision to a larger customer base. Therefore, rather than following an incremental transition process across the product-service continuum, the challenge of servitization for firms is to balance the co-existence of different roles of the service-related business models on a continuous basis.

Studies have suggested three main motivations or drivers of servitization: competitive motivations, demand-based motivations and economic motivations (Baines et al., 2009; Wise and Baumgartner, 2009; Olivia and Kallenberg, 2003). Competitive motivations are primarily driven by the need to differentiate the tangible product offering, which might be commoditized through service offerings. Demand-based motivations are primarily driven by customers wanting to undertake certain activities themselves or outsourcing some non-core activities to reap the benefits of scale economies from their suppliers. This implies that manufacturers might need to provide such 
additional services to support the activities of their customers. Economic motivations are primarily driven by the need to find a new sustainable source of revenue in order to overcome stagnating growth of the product market, to leverage the often more profitable service market and to provide a more stable revenue stream by hedging against the peaks and troughs of product sales. These motivations could be either defensive, in order to help reduce costs for customers and to lock out competitors, or offensive, in order to encourage growth for the relevant stakeholders (Baines, Bigdeli, Bustinza, Shi, Baldwin and Ridgway, 2016). In a recent paper, Raddats, Baines, Burton, Story and Zolkiewski (2016) developed a deeper understanding of these motivations for servitization by examining how they are influenced by the complexity of the product offering. The study shows that competitive motivations for servitization appear to be most relevant for suppliers of noncomplex products, while economic motivations are relevant for suppliers of complex product-service systems. Moreover, demand-based motivations are relevant for manufacturers across the product complexity spectrum, with an emphasis on cost savings and improving service quality, especially when activities are outsourced.

Service-driven transformation requires the reconfiguration of fundamental elements of the product-service offering, a new proposition development process, sales and delivery process and the value network. Such a process of servitization requires reactivating - altering the set of activities; relinking altering the linkages between activities; repartitioning - altering the boundaries of the focal firm; or relocating - altering the location in which activities are performed (Dos Santos, Spector and Van Der Heyden, 2015). Studies have shown that enabling such service-oriented transformation to occur might require different organizational forms and even different organizational structures (Biege, Lay and Buschak, 2012). This includes moving from a functional form to a matrix structure to enable bettercoordinated change, or having a separate dedicated unit to implement the new service proposition (Rasmussen and Foss, 2015). Moreover, new performance-measurement systems are required to support the new service orientation and enable the change initiative while managing incentive-based conflicts among employees ( $\mathrm{Ng}$ et al., 2011). The transition to services requires a shift in management perspective (Barnett, Parry, Saad, Newnes and Goh, 2013; Alvarez, Martins and Terra da Silva, 2015). Therefore, organizations need to change in order for servitization to take hold.

The process toward the servitization of manufacturing is described as a transitional one (Oliva and Kallenberg, 2003; Vendrell-Herrero, Parry, Bustinza and O'Regan, 2014). The steps involved in the transition to service identified in the literature fall into two broad groups. The first is related to the strategic level of the transition to services and the second to the operational level. Table 1 summarizes these steps.

Twenty-one steps are identified at the strategic level and seven at the operational level. The majority of these steps are vaguely defined in the literature, and highly independent and discontinuous (non-sequential) from one another, as they have naturally emerged from various disconnected studies. Lim et al. (2012) and Bakas et al. (2013) attempted to provide some sequential steps, but they are still very general and closer to the definition of a typical project management process (see Table 1). 
The four steps most frequently discussed at the strategic level are as follows: 1) start with product-related services and then extend the service offering; 2) establish a service culture; 3 ) prepare and identify the potential service-products that will be on offer; and 4) confirm and select the service design or service concept and pilot study (Oliva and Kallenberg, 2003; Davies, 2004; Gebauer et al., 2006; Neely et al., 2008; Kindström, 2010; Martinez et al., 2010; Salonen, 2011; Lim et al., 2012; Barnett et al., 2013; Marques et al., 2013; Bakas et al., 2013).

The two most frequent operational steps are as follows: 1) establishing the employees as operant resources; in other words, these are the service-related knowledge and skills of employees; and 2) implementation of performance management and measures for the service business (Mont, 2002; Auguste et al., 2006; Vargo et al., 2007; Bolton et al., 2007; Martinez et al., 2010; Baines et al., 2011; Baines et al., 2013; Baines et al., 2014).

In addition, a small body of literature discusses the point of destination of the transition to services. Particular attention is paid to the "visualization of the intangible value of service offerings, the definition of value for the customer, and how value creation and delivery would take place" (Kindström, 2010; Salonen, 2011; Smith, 2012; Bakås et al., 2013).

\section{Table 1: Steps in the transition to services from literature}

\subsection{Business transformations and organizational change}

Servitization is a form of business transformation that calls for organizational change (Vendrell-Herrero et al., 2014). The transition to services across the spectrum of services might require different approaches to managing change. On the one hand, studies have shown that service provision needs to be planned with incremental changes as the firm moves through the different phases of servitization (see Oliva and Kallenberg, 2003; Tukker et al., 2004). On the other hand, studies have shown that a more adaptive approach is needed, as the servitization journey requires increasing engagement between the customer and the service provider, which entails a process of experimentation and learning (Martinez et al., 2010). However, recent studies have argued that such an incremental or adaptive approach might not be optimal, whereby there is a need to provide complex services where the outcome is emergent and unknown from the outset. In such a case change is required across all stakeholders covering strategy, organization, enterprise management, contracting, culture and operations management (Barnett et al., 2013). Therefore, a more holistic, system-wide change is required across the value chain, network of relationships and performance-management systems in order to affect the servitization strategy successfully (Fang, Palmatier and Steenkamp, 2008; Gebauger, Edvardsson and Bjurko, 2010). Such a transition demands a new mindset driven by cognitive reframing that should pervade the entire firm, its network and the ecosystem in which it operates 
(Gebauger, 2008; Visnjic-Kastalli and Van Looy, 2013; Ng, Ding and Yip, 2013).

At a broad theoretical level, organizational change management has been dominated by two approaches: first, there is the punctuated equilibrium model, which assumes that long periods of small, incremental change are interrupted by brief periods of discontinuous, radical change (Tushman and Anderson 1986; Gersick, 1994). Alternatively, the theory of continuous change suggests that change is not episodic but endemic to the way in which organizations operate, with the ability to engage in rapid and relentless continuous change, which is "a crucial capability for survival" (Brown and Eisenhardt, 1997; Langley, Smallman, Tsoukas and Van de Ven, 2013).

Additionally, scholars have highlighted different typologies of organizational change process. For example, Van de Ven and Poole (1995) and Van de Ven and Sun (2011) identified four process models of organizational change: teleology (planned change), dialectics (conflictive change), life cycle (regulatory change) and evolution (competitive change). Other scholars have proposed helpful variations of these four basic models of organizational change (see Huy, 2001; Weick and Quinn, 1999). A teleological process involves planned change based on a group of participants agreeing and moving to achieve a shared organizational goal. A dialectical process involves different organizational units facing conflict and confronting one another on such conflicting issues. The life-cycle process involves recurrent and predictable organizational change in a regulated manner. Finally, the evolution process involves multiple units within or between organizations competing for scarce resources. These process models differ in terms of whether they apply to single or multiple organizational entities and whether the change process follows a prescribed sequence or is constructed (emerges) as the process unfolds. Each theory views the process of development as unfolding in a fundamentally different progression of change events and being governed by a different generative mechanism or "motor". These four models of change can be seen as alternative perspectives on a single phenomenon or as different phases of change across time.

Such change processes may unfold over a number of phases of emergence, development, implementation and diffusion (Hargrave and Van de Ven, 2006). The emergence phase involves actors constructing a new envisioned state, but before mobilizing plans and resources. The development phase is where different networks of organizational actors propose their competing claims for alternative proposals for organizational change. This is followed by implementation and diffusion once a particular vision has won the political campaign and becomes legitimized. The four process models of change could play a dominant role in each phase of the change process. This requires management to take action and also to reflect on that action in order to adjust their model to fit the process of change unfolding within an organization. However, the empirical evidence about how such an organizational change journey unfolds, and its implications for the corresponding process theory of change, have received little attention. Our study aims to explore which of the two schools of thought concerning change are most relevant to servitization.

\section{Method}


Three independent service journeys were studied in order to understand the service journey from the very beginning to the present. Three criteria were used to select our cases: the influence of technology on the firms' servitization; the maturity of the firms' transition to services; and the servitization contexts.

Tongur and Engwall (2014), Baines, Bigdeli, Bustinza, Shi, Baldwin and Ridgway (2016) and Breitbach and Maglio (2016) have highlighted the need for further research into "the influence of technology on servitization". The three cases were primarily selected on the basis of the role and influence of technology (such as digital technology, loT and data analytics) on the service offering(s) and service business model(s). These three cases are an animal well-being firm, a process engineering firm and a learning provider firm. The three cases range from having intermediate to advanced influence of technology.

Next, to enable a fair comparison of the different service journeys, we further selected cases with a similar kind of "maturity in the transition to services". All selected cases actively began their servitization journeys seven years ago.

Finally, a complementary selection criterion was the "servitization context". Parry, Vendrell-Herrero and Bustinza (2014) suggested the extensive learning benefits of studying contexts that are distant from manufacturing ones, such as music and creative industries, in understanding the servitization phenomena. Thus, we diversified our case selection and selected a typical mainstream case, "the engineering case", and two other contexts that go well beyond manufacturing - "the well-being case and learning case".

The service journey is our unit of analysis. A qualitative research strategy, supported by interviews and focus groups, is an appropriate method with which to study the service journey comprehensively (Edmondson and McManus, 2007).

Fifty-two interviewees participated in this study. In order to build a complete and objective understanding of the service journey, we interviewed the president, vice presidents, directors, managers, technology developers, service coordinators and customer-facing employees. The interviews were guided by a structured questionnaire, documented in our research protocol. The interviews yielded 3,390 minutes and 1,062 pages of transcripts.

The interview transcripts were analyzed using content analysis, coding and pattern identification. Finally, a descriptive analysis of each journey fed the cross-case comparisons. The cross-case analysis colour-coded the individual journeys, highlighting the journeys' intersections.

Twenty-eight initial steps explain the service journey. Then, eight more steps were added through a "feedback-focused group" with ten senior managers. In total, 36 steps in the service journey were identified. We analyzed and clustered them into 12 themes, which became the "stages" and "steps" of the service journey.

The 12 stages of the service journey evolved and created the service strategy model, based on the feedback from "two validation-focus groups" the first in July (with 22 participants) and the second in September (with 12 participants).

\section{Firms' backgrounds}


The participating firms in this research are three global product leaders - an animal well-being firm, a process engineering firm and a learning provider firm. Their annual sales are similar, with 5,500 million US dollars being the average sale per annum per firm (with a variation of $\pm 6.5 \%$ ).

Traditionally, the reputation and brand image of these firms comes from the successful positioning of their products in their respective markets. All three operate in completely different environments, and yet they share a common strategic goal - "competing on services". Historically, their business models have been developed upstream, with strong resonance in product development and manufacturing, as observed in Table 2.

To date, despite their upstream business models and their product-oriented core competencies, they have all been infusing services into their strategies and operations. They all are moving away from basic services such as spares, repairs and reactive maintenance, to more complex (customized) services. In this paper, when we refer to services, we mean complex services.

Table 2. Firms' backgrounds

\begin{tabular}{|c|c|c|c|}
\hline & \multicolumn{3}{|c|}{ Firms } \\
\hline & Well-being & Engineering & Learning \\
\hline $\begin{array}{l}\text { Principal } \\
\text { business }\end{array}$ & $\begin{array}{l}\text { Development and } \\
\text { manufacturing of animal } \\
\text { health and well-being } \\
\text { medicines, diagnostics } \\
\text { and genetics. }\end{array}$ & $\begin{array}{l}\text { Process technology and } \\
\text { components for } \\
\text { sophisticated } \\
\text { production processes. }\end{array}$ & $\begin{array}{l}\text { Education, consumer } \\
\text { publishing and business } \\
\text { information. }\end{array}$ \\
\hline Business model & Upstream & Upstream & Moving downstream \\
\hline $\begin{array}{l}\text { Current core } \\
\text { competencies }\end{array}$ & $\begin{array}{l}\text { R\&D, manufacturing of } \\
\text { bio-pharmaceutical } \\
\text { products and direct } \\
\text { selling model. }\end{array}$ & $\begin{array}{l}\text { Development and } \\
\text { installation of process } \\
\text { technology. }\end{array}$ & $\begin{array}{l}\text { Development of } \\
\text { learners' assessments } \\
\text { and certification. }\end{array}$ \\
\hline Customer focus & $\begin{array}{l}\text { Mainly on companion } \\
\text { animal and livestock } \\
\text { veterinarians and } \\
\text { livestock producers. } \\
\text { Moving to pet owners. }\end{array}$ & $\begin{array}{l}\text { On product specification } \\
\text { and technology to } \\
\text { support customers' } \\
\text { processes. }\end{array}$ & $\begin{array}{l}\text { On education and } \\
\text { learning services for } \\
\text { academic institutions. }\end{array}$ \\
\hline
\end{tabular}

\section{Firms' service journeys}

The progression of a firm's journey in the adoption of services is the main line of enquiry. The description of the progression of facts and steps seeks to emphasize the experience and authenticity of these journeys.

A complete story of these journeys cannot commence without analysis of the triggers that motivated the change. In other words, what caused these firms to embark on the exploration of services? Therefore, this section begins with an analysis of the logic behind shifting to services and then moves to the 
analyses of individual service journeys. The next section discusses the findings from the cross-case analysis. Throughout this paper, these journeys are referred to as the well-being, engineering and learning service journeys.

\subsection{Logic to embark on the journey to services}

The journeys all began around seven years ago, when these firms observed a progressive change in their customers' consumption patterns and the surrounding environments.

"...Students are buying less printed books... Shift to on-line digital markets... The economics of the Internet distribution", were some of the triggers that a vice president of the learning firm highlighted for the shift to services. These triggers have consequently driven a steady decrease in the sales of printed books. The rationale behind this firm adopting services was to "increase new sources of revenue generation".

In the well-being firm, a vice president commented: "We've got a heavy research and development base... big investments in discovering new treatments... product to market is 5 to 10 years. This model does not generate new customers... but creates deeper penetration on existing ones.... For us, product innovation is beginning to slow down, it's becoming extremely expensive." A senior manager of services added: "...what happens next is ... this new area of innovation is now around digital, services and differentiation." For this firm, according to an executive vice president, the rationale behind services was to "increase customers' loyalty and add more value to customers than competitors through continuous and progressive differentiation".

The vice president of services of the engineering firm emphasized that, “... traditionally, our services were defined as the supply and the installation of spare parts, end of story... this was a protected area because it was very profitable, but not fully exploited!" The firm's rationale for adopting services was: "We know that services will be the differentiating factor if a customer is going to continue to do business with us or possibly will change supplier."

All three firms recognized the increasing difficulty inherent in retaining their leadership and differentiating from their competitors by competing based solely on products. They equally agreed that in order to remain competitive, they would need to innovate their existing customer offerings. They have therefore embarked on a journey to explore different service strategies to diversify their portfolios.

For the last seven years, these firms have been actively exploring and implementing services. They are innovating their service portfolios by creating a diversity of services ranging from basic to complex. In the next 5 to 10 years, the learning firm expects "services" to be the main revenue generator. On the other hand, the well-being and engineering firms expect "services" to contribute to their total value propositions and to de-risk their competitive positions.

\subsection{Well-being service journey}

Seven years ago, the strong corporate commitment to products did not lend itself to an easy transition to the service journey. As a senior director of corporate services explained: "If we wanted to take Services seriously, we did not have many options but to position Services within our company's vision." 
Hence, this journey began by "creating the vision for selling services and solutions" and then "positioning this vision as a global vision". This was followed by "getting leadership support to take risks and make investments" for the exploration of services.

At this point in the journey, it was difficult to gain support from board members to set and deploy resources "in a decentralized way". However, this proved to be a crucial element, as "it shows the entrepreneurial approach and commitment of the firm to grow services", as emphasized by a senior director of service development. Furthermore, it was followed by "appointing the exploration team with resources and time".

In this journey, agreeing the framework for the exploration and development of services took a tremendous amount of coordination between the two service-leading regions - North America and Europe. The paradigm shifted to "evolve from features to customers' needs and the impact on service selling training", "identifying the opportunity gap: customer needs vs demands" and "explore: starting from the places closest to customers". The journey then proceeded to "rolling out these changes to all functions and getting active participants from the top".

Instead of progressing toward consolidation of the foundations of the service-operating model, this journey retroceded to the early steps to the "assessment of existing resources and gaps". Then, it proceeded to "define the service innovation approach" and "the acquisition of new capabilities". A business solution manager added "... returning to the early steps is frustrating... takes concentration away from the progression on services and extends the duration of the journey... but we learn things that initially we overlooked..."

The journey moved forward to establish a delivery model by "developing and managing service contracts" and "learning to price new services". It also "establishes the discipline to process, go, define, deliver and validate services". Service design is centralized and largely entrepreneurial. Over the years, this firm has developed and launched more than twenty services with various levels of complexity and purposes. Over the last three years, the firm has been aggressively trying to move toward the experimentation of complex services for B2B and B2C. Part of this firm's journey is about managing the partnership to complement its existing service skills. As more services are piloted and tested, the journey takes steps back to the initial discussion about the reallocation of "funding: unit vs central".

Services have been launched predominantly in the US and Europe. As the portfolio of services has grown in both parts of the Atlantic, there has been an evolution in the selection of services in which to invest and to launch on the market. An early "...framework of criteria to select services with the strongest potential to be commercialized" was introduced, which brings structure and formalizes the service-selection process.

Currently, the journey is moving toward a more mature phase, where different ways to optimize service innovation, commercialization and delivery are taking place. For instance "...optimize... the way to regionalize... get higher quality lower cost-price... keep the modeling \& analysis for the optimization of services".

\subsection{Engineering service journey}


The strong legacy of product innovation and large business fragmentation has made it difficult for this journey to take off. As the head of service delivery explained: "... grown by mergers and acquisition has massive implications... some business segments are more mature in selling services than others, offer different types of services and have different ways to deliver them..." According to a vice president, this journey therefore started from the very basics in order to "... get a common definition of services and solutions' selling across the firm". Soon, the firm moved to "... define services as part of the corporate strategy" and then to "... create vision for solutions' selling", the director of services explained.

The journey continued by “... appointing the leading exploration team [across and within segments]" and then proceeded to "... get resources closer to the vision", as described by a segment president. While there is evidence of investments and resource allocation for the design and exploration of services, they have generally come from individual segments as opposed to a central account. This means that individual segments are accountable for the success or failure of services, but are still rewarded according to overall revenue generation, where services often contribute a minimal amount. Therefore, segments consciously limit the exploration of services.

The firm tried to "...open, share and harmonize information [across segments and functions]", as the service manager explained. The lack of a common information system - there are several as a result of numerous mergers and acquisitions - makes this journey more challenging.

In moving forward, the firm has focused on "...designing the service delivery and service selling strategy" and "... defining the service approach to innovate", explained a segment president. Traditionally, service design is incremental, but it is gradually moving beyond the basic services. The exploration and launch of services are decentralized and ad hoc. Recent structural reorganizations have centralized the strategy and management of services, which benefits the growth of the services portfolio and encourages the development of in-house service skills. Currently the firm's journey is focusing on "... establishing a discipline to process, go, define, deliver and validate services", and "...monitoring and communicate results", added the director of services.

\subsection{Learning service journey}

For more than a decade, top leaders have had numerous isolated discussions about selling services in the education sphere. However, altogether this actively began around seven years ago, as the vice president of strategy explained: ".... when we realize that our traditional businesses are coming under pressure and at the same time clients are asking us for services that we didn't offer or had in our catalogue, this creates an enormous pressure that made us wake up and react." Building on this, the firm took the opportunity, first, to "...establish the sense of urgency of the situation" across all divisions and, second, to "create a long-term business case", as the head of service delivery explained. It was then that the firm began to "create general awareness to make the shift to services". To get the message across the entire firm, it used the analogy of the bankruptcy of Kodak's instant camera and its inability to react to the market and technology revolutions. The analogy made people more receptive to welcoming services. 
"The development of the responsible head for the service business model and testing" was the next step in formalizing the initial infusion of services in the firm, as the director of business transformation explained. This was followed by "...understanding own firm resources - soft skills, behaviors and culture - processes, requirements and gaps", the vice president of service solutions added. Subsequently, the firm began to "... exploit, explore and experiment...". It was then that "... we roll[ed] out the change to all functions and get active participants from the top", the director of leadership explained.

This journey took a step back to learn lessons about how, and to what extent, to "... co-develop services with customers". It then moved forward by proactively "seeking new [services] opportunities - analyzing service data and looking for opportunities to make a positive impact [on customers' business performance]", explained the director of business transformation. During the journey, the firm became trapped in a cyclical phase of co-development and active identification of new services that overlooked the overall management of these new services, such as cost-benefit, correct pricing, and so on. For instance, among tensions arising in this service journey were funding policies, length of service incubation and evaluation mechanisms to terminate unprofitable services, for example. Service design grows organically through enthusiastic groups of employees on key selected institutional customer businesses. The firm is building a wide portfolio of services, from productbased to results-oriented services, using efficacy measures to demonstrate the value of the services to customers and end-users. For a long time, the management of service design and development has been unstructured, but over the last three years strong emphasis has been placed on the strategic management of service development. A large part of this journey has been focused on the development of service skills. The firm develops its service skills through a combination of acquisitions and in-house learning.

After a while, the journey moved to '... building up people's jobs: services' targets, key performance indicators (KPI) and individual KPI", explained the head of delivery. The president of integrated solutions added: "We eventually learnt that ...top management has to be very involved. They need to manage and run the business, which are two different things." Then the journey moved to more proactive steps - it "... encourages the use of the new business model and good practices [on a daily basis]', highlighted the vice president of emergent models.

The longest part of this firm's journey, explained the director of business transformations, has been to "... change people's minds to services"; "... trying to build up services internally and organically, in a company that is primarily a product-based company is a very difficult step... different people's mindsets and not all of them understand that services are not products and need to be treated different", added the president of integrated solutions. "Since our new CEO took over around three years ago, there is stronger support and focus on services", added the vice president of service solutions. Currently the firm is focused on improving service governance - standard service processes designed to speed up the cycles, from service design and incubation to the point of sustainable commercialization.

\subsection{Service development in transition: the pace of change}


The evolution of the development of services of the three cases over seven years is illustrated in Table 3. A number of common themes or trends cutting across the three different cases were observed.

An early trend at the beginning of the service journey, during the first three years of the firms' transition to services, was to build up basic services and then move carefully and incrementally out from the basic services, adding a few intermediate services. These intermediate services are user-oriented services, with only a small degree of customization (see Baines and Lightfoot, 2013). This early incremental transition is aligned with previous studies around the servitization continuum of service offerings (see Oliva and Kallengberg, 2003; Tukker, 2004; Gebauger, 2008).

After the fourth year in the transition to services, something interesting took place across the three cases. We observed that the pace of change evolved from the "incremental development of services from basic to intermediate" to "two concurrent streams of service development".

1) The first stream kept the incremental peace of service development by building on the current intermediate services.

2) The second stream accelerated the service development by exploring and adding more complex (highly customized) services to already existing service portfolios.

This pace of change shown in this longitudinal analysis of the service is not fully explained by the previous literature. Our research is consistent, to a certain extent, with the previous research on the incremental continuum of service development (Oliva and Kallengberg, 2003; Tukker, 2004; Gebauger, 2008), radical services (Loving, 2011; Smith, 2013) and the co-existence of different types of service across the service continuum (Kindström and Kowalkowski, 2015), but it argues that these changes occur at different points in time during the service journey.

Table 3. Service development over time

\begin{tabular}{|c|c|c|c|}
\hline & \multicolumn{3}{|c|}{ Firms } \\
\hline Time & Well-being & Engineering & Learning \\
\hline $1-3$ years & $\begin{array}{l}\text { Basic services close to } \\
\text { the product, such as } \\
\text { certification of } \\
\text { vaccination, diagnostic } \\
\text { services. }\end{array}$ & $\begin{array}{l}\text { Basic services such as } \\
\text { installations, spares and } \\
\text { repairs. }\end{array}$ & $\begin{array}{l}\text { Basic service supporting } \\
\text { products, such as maths } \\
\text { lab software. }\end{array}$ \\
\hline $4-7$ years & $\begin{array}{l}\text { 1) Continue with } \\
\text { intermediate services, } \\
\text { such as consultancy } \\
\text { and performance } \\
\text { indexes. ICTs enable } \\
\text { the service interactions. } \\
\text { 2) Explore more } \\
\text { customized services, } \\
\text { such as real-time health } \\
\text { check and advice } \\
\text { services powered by } \\
\text { apps. ICTs are an } \\
\text { integral part of these } \\
\text { customized services. }\end{array}$ & $\begin{array}{l}\text { 1) Continue with } \\
\text { intermediate services, } \\
\text { such as training, } \\
\text { condition-based } \\
\text { monitoring and predictive } \\
\text { maintenance. ICTs enable } \\
\text { the service interactions. } \\
\text { 2) Explore more } \\
\text { customized services, such } \\
\text { as total plan management } \\
\text { (in pilot) and proactive } \\
\text { maintenance. ICTs enable } \\
\text { the service interactions. }\end{array}$ & $\begin{array}{l}\text { 1) Continue with } \\
\text { intermediate services, such } \\
\text { as diagnostic assessments } \\
\text { and benchmark } \\
\text { assessments. ICTs enable } \\
\text { the service interactions. } \\
\text { 2) Explore more } \\
\text { customized services, such } \\
\text { as online tutoring and } \\
\text { mentoring solution } \\
\text { outcomes measured by the } \\
\text { service efficacy. ICTs are } \\
\text { an integral part of these } \\
\text { customized services. }\end{array}$ \\
\hline
\end{tabular}




\section{Findings through a cross-case comparison}

In total 36 steps in the service journey were identified. Twenty-eight initial steps emerged from the interviews and eight more were added from the first feedback focus group. We analyzed and clustered the 36 steps into 12 themes, which became the stages and steps of the service journey.

The firms' service journeys are illustrated in Figure 1. The journeys are colourcoded and the chronological steps of each journey are indicated on the righthand side of the steps.

Figure 1: Service journey: cross-case comparison

All three service journeys have different starting points. The learning journey began by creating a burning platform to attract the firm's attention to services. The well-being journey began by positioning services within the firm's vision. Finally, the engineering journey began by defining services and positioning them as part of the corporate strategy. Kindström (2010), Salonen (2011), Smith (2012) and Bakås et al. (2013) highlighted the importance of the point of destination in the transition to services, particularly the definition of the end value for the customer. Conversely, there is a lack of literature explaining the point of departure in the transition to services. This study shows a variety of points of departure.

The general notion of a single-path journey to services is not supported by our results. On the contrary, the three journeys show three different paths. Oliva and Kallengberg (2003), Tukker, (2004) and Gebauger (2008) discussed the incremental continuum of services during the transformation and inferred the idea of a single-path journey on the continuum. The preliminary analysis of our cases shows that there is no single-path journey but largely evolutionary journeys; a deeper cross-case comparison enabled us to make the following observations:

a) All three firms have shared some common steps during their journeys to services. These steps are localized on four shared stages of the service journey: (1) resources, (2) leadership, (3) service delivery model and (4) rules of change (see Figure 1).

b) After positioning services at the core of the firms' vision and strategy, creating "leadership" and "resources" are the subsequent stages that all three journeys followed. Then, in the later stages of their journeys, all three firms have come back, revisited and improved the initial steps in the "leadership" and "resources" stages. This is achieved once a more mature understanding and experience of services are reached.

c) The "service delivery model" is the stage of the journey on which greater emphasis has been placed by all three firms. 
The chronological order of steps differs from journey to journey. In all three journeys, the back-and-forth sequence of steps is observed. Various interviewees, for example, the innovation director of the well-being firm, described their journeys as "...emergent and organic...". A service manager from the engineering firm added: "... In some occasions, we feel this is a trial and error approach." The theory of continuous change suggests that change is endemic, rapid and relentless (Brown and Eisenhardt, 1997; Langley, Smallman, Tsoukas and Van de Ven, 2013). This theory highlights the importance of understanding the process of change and calls for more research in order to understand change at a micro-level (Van de Ven and Sun, 2011). Parallel to this, the servitization literature calls for a deeper and clearer explanation of how the transition to services is made (Baines, Bigdeli, Bustinza, Shi, Baldwin and Ridgway, 2016). The chronological order, and the back-and-forth sequence of steps shown in this study, explain the microprocesses of how incremental change processes unfold. This is the first study in the transition to services to demonstrate the micro-process of how change unfolds.

The "co-development" and "exploration" stages are important in designing services (Meyer-Goldsmith et al., 2002; Vargo, Maglio and Akaka, 2008). The well-being and learning firms have incorporated these stages in their service journeys by trying to establish some early guidelines and processes to codevelop, explore and exploit services. The initial guidelines and processes were incomplete. As time has passed, these early guidelines and processes have evolved and improved. Other studies have highlighted the importance of experimentation and learning as key capabilities in the organizational transition to services (Martinez, Bastl, Kingston and Evans, 2010).

From the learning perspective, it was observed in each particular case that every launch of a new service was vaguely informed by previous experiences and therefore treated as a new project. Across the three journeys, there has been a general tendency not to document the lessons learnt from successes and failures. Recently, the well-being journey has begun to document the decisions and actions of the service design and delivery as part of its normal routine. Starbuck and Hedberg (2015) highlighted the importance of building up organizational learning, particularly in times of change. They argued that learning arises from automatic reactions to performance feedback, and learning from successes is as important as learning from failures. Our three firms eventually began building up their learning about the transition to services in an emergent and unplanned manner. The well-being and learning firms are building it up faster than the engineering firm.

The feedback focus group provided an opportunity for participants to analyze retrospectively their service journeys up to this point, to question the decisions and chronological steps and to enhance their learning. A technology developer from the well-being firm commented, "... now, I can see why it did not work out the first time around... it took us too much time”. "... I can clearly see the steps and where to go... it is simple... but before we did not have this clarity...", the vice president of service solutions from the learning firm added.

Discussions about the service journey findings evolved from the "it is" status to the "should be" status. In other words, after learning about these three service journeys, the next logical question that people asked was: "What 
are the critical elements that should be present in any service journey to ensure a smooth transition to services?"

To answer this question, there were two additional focus groups (22 and 12 participants correspondingly). All participants were actively working in servicetransitioning firms. The first focus group built the service strategy model from the steps of the service journey and the second focus group validated the service strategy model.

In the first focus group the 12 stages of the service journey (including their corresponding steps) were taken apart and then brought together again to find a logical sequence (seven prototypes of this logic were created until everyone agreed on the most comprehensive and coherent one). Then, each stage was analyzed, some steps were moved from one stage to another, some stages were renamed, others were merged and a new one emerged. For instance, the "burning platform" stage of the journey evolved and became the "assessment of the market and internal readiness". The "structures and governance" stage was built from the steps from the service journey. In conclusion, the twelve stages of the service journey evolved into seven stages and created the "service strategy model".

In the second focus group, this model was validated with the last focus group of twelve vice presidents, directors and senior managers of five participating firms. The service strategy model has seven validated stages, which are the critical element for the transition to services (see Figure 2). All stages are interdependent and need to operate concurrently to enhance service performance.

Figure 2: Service strategy model

\section{Discussion}

This study has explored which of the two change management theories are most relevant to servitization: the punctuated equilibrium model (Tushman and Anderson 1986; Gersick, 1994) or the continuous change model (Brown and Eisenhardt, 1997; Langley, Smallman, Tsoukas and Van de Ven, 2013). This research observed that service journeys that are studied consistently follow the continuous change model, where change in servitization is not occasional but endemic in the way in which firms typically operate. Furthermore, this continuous change is neither logical nor structured but much more emergent and intuitive.

The majority of the literature on the service journey reports on studies of challenges and enablers (Mont, 2002; Gebauer, 2006; Marques et al., 2013; Baines et al. 2014). It seems, however, that there is limited reporting of in-depth longitudinal studies explaining the details of individual firms' step-bystep service journeys (Vendrell-Herrero et al., 2014; Baines, Bigdeli, Bustinza, Shi, Baldwin and Ridgway, 2016). In this study we sought to overcome this shortcoming by explaining in some detail the actual service journeys undertaken by the three firms. We used these experiences to create an illustrative "service journey route map" (Figure 1). In each case, the firm's 
service journey was evolutionary and emergent. Our retrospective analysis suggests three reasons for this. First, our three case study firms were deeply routed in their traditional products. They displayed technical and organizational excellence in terms of product development and delivery, but had to learn - often through trial and error - about services. Second, the paucity of extant literature and verified frameworks for explaining the service journey meant there was little reference matter available (as also highlighted by Kowalkowski, Windahl, Kindstrom and Gebauer, 2013; and Kindström and Kowalkowski, 2015). Third, our analysis shows that the shift to services involves some elements of evolution or co-evolution. Van de Ven and Sun (2011) supported the idea that evolution is one of the most common process models of organizational change. This change process is either prescribed or constructed (emerges) as the process unfolds. This research shows that firms adapt their business models, processes and service offerings as their customers' needs and aspirations change in a co-evolutionary way with their closest ecosystem partners. The extant literature on process-change models focuses on the internal dynamics of the change journey by examining the generative mechanism of change, primarily from internal stakeholders' perspectives and conflicts. We extend such a change process to include the wider ecosystem of partners, from customers to suppliers, in contributing to the generative mechanism of change. These cover the four process models of change, including life cycle and evolutionary convergence aspects and teleological and dialectical divergence aspects.

\section{Pace of change}

Previous studies have not fully explained the pace of change in servitization. This longitudinal research shows that during the first three years the organizations built up their basic services and then carefully added a few intermediate services to their service portfolios. After the fourth year, two parallel streams of change arose. The first one kept the incremental peace of service development, focusing on basic and intermediate services. The second stream accelerated the service development by exploring and adding more complex (highly customized) services.

To a certain extent, our research agrees with both the incremental continuum of service development from Oliva and Kallengberg (2003), Tukker (2004) and Gebauger (2008) and the radical development of services from Loving (2011) and Smith (2013). Incremental and radical service development co-exist, but only at later stages of the service journey. This research builds on the research of Oliva and Kallengberg (2003), Tukker (2004), Gebauger (2008) and Kindström and Kowalkowski (2015) by providing a clearer explanation of the service development dynamics, particularly the pace of service development (when) and the types of service being developed (what). Our research extends the research of Kindström and Kowalkowski (2015) by further explaining when the coexistence of basic, intermediate and complex services occurs across the service continuum.

Similar steps, different journeys 
Three key factors differentiate the journeys of our case study firms - the type of steps, the chronological sequence of these steps and their actual implementation.

First, the type of steps taken in a journey could render the journey explicit and useful or ambiguous and meaningless. For instance, the engineering journey provided less clarity (fewer steps) on the co-development, exploration and service delivery stages. This led to ambiguity, until individual teams determined how to overcome their own problems in terms of exploring and delivering services. The conventional model of change assumes phases of change, from emergence and development to implementation and diffusion. The literature acknowledges that there might be "back and forth" elements between these stages. However, the literature on such a model is silent on the degree of uncertainty through a process of political bargaining among stakeholders that contributes to the legitimacy of a particular program of change (Hargrave and Van de Ven, 2006; Van de Ven and Sun 2011). In contrast, our study shows that such a process of increased clarity might not be the only course of progression; rather, there could be increased ambiguity from the change journey.

Second, the chronological sequence of steps influences the logical evolution of a journey. The logical sequence of steps precludes a journey from forward and backward paths, which consequently impacts the length of the journey. For instance, the learning and well-being journeys have both followed the step called "understand own firm resources, processes, requirements and gaps". The learning journey has followed a natural and logical step of "appointing the service leader" and then "understanding the resources...". On the contrary, the well-being journey has moved forward toward the codevelopment and exploration of services and then realized that it has to go back to "understand the firm's resources, processes and gaps" before advancing the exploration of services.

Third, the implementation of the steps could make one journey look very different from another. For instance, the well-being and learning journeys have both followed the step called the "exploitation/exploration/experimentation of services". In the case of the wellbeing firm, as a segment president explained, it implements service exploration and experimentation processes where "... employees are allowed not to always meet expected outcomes... we [all employees] need to learn and improve". On the other hand, the learning firm expected each service experiment to succeed and progress toward the commercialization of services: "... learning from failures is not heavily penalised but not welcome", as the head of direct delivery explained. "The chronological sequence of steps" and "the implementation of steps" have influenced the logical evolution of the engineering, well-being and learning journeys, as explained by the literature on "the phases of change processes" (Van de Ven and Sun, 2011). In particular, our study provides empirical evidence to support a contingency view of the dominance of the different process models of change across the change journey. It shows that the dominance and sequencing of planning, conflict, regulation and competition across the change phases are contingent on several factors, such as the role of leadership, the forces of customer preferences, the readiness of the ecosystem partners, as well as the resource availability and allocation processes within firms that are servitizing. In doing 
so, our study provides a nuanced understanding of the phases of the change process - from emergence and development to implementation and diffusion - in the transition to services. Such in-depth understanding of the change process at the micro-level is important, as it unveils how change actually happens and, hence, contributes to both the theory and practice of critical business transformations such as servitization (Langley, Smallman, Tsoukas and Van de Ven, 2013; Baines, Bigdeli, Bustinza, Shi, Baldwin and Ridgway, 2016).

Co-existence of different types of service on a service journey

Previous research suggests that the capabilities, governance, structures and resources required to offer basic services (Baines and Lightfoot, 2013; Biege, Lay and Buschak, 2012) or product-based services (Tukker et al., 2004), such as spares and repair services or consulting and training services, do not differ significantly from traditional product-based capabilities and delivery processes. Therefore, it could be inferred that a journey to basic or productbased services would not be a drastic one.

Our research shows that the three firms studied have gradually offered a variety of services, ranging from product-based services to more complex ones. ICTs generally play an important role in enabling service interactions between actors (Breitbach and Maglio, 2016; Eloranta and Turunen, 2016); however, we observed in our study that in the provision of complex services by the well-being and learning firms, ICTs were an integral part of the service provision.

We observed that, at a certain point during the journeys, a critical and common problem across all three service journeys is constantly having to manage the balance between customized (complex) and standardized services (scaled services). In particular, the well-being and learning journeys have a wide variety of types of service. Our research findings support the assertion of Kindstrom and Kowalkowski (2015) that an important issue to explore is the co-existence of different types of service and their corresponding business models; however, we would argue that such enquiries also need to take into account the service journey.

Three complementary and yet incomplete journeys

An interesting question that this study raises is whether the full shift to services requires firms to complete all twelve stages outlined in the service journey route map. None of the firms studied had completed all twelve stages; yet in workshops and discussions they recognized the value of the steps they had missed or not yet begun. Our hypothesis is that for firms starting out on the shift to services, the service journey route map will provide a valuable guide to the transformation they are about to undertake.

\section{Conclusions}

All three firms recognized the increasing difficulty of retaining their leadership and differentiating from their competitors by competing based exclusively on products (Cusumano, Kahl and Suarez, 2014; Eloranta and Turunen, 2016). They equally agree that, in order to remain competitive, they need to innovate their existing customer offerings (Raddats, Baines, Burton, Story and 
Zolkiewski, 2016). They have therefore embarked on a journey to explore different service strategies in order to diversify their portfolios.

This paper investigates the basic and yet overlooked question, "What does a service journey look like?" It concludes that service journeys do not follow a single path or even share the same point of departure.

\section{Implications for theory}

The paper offers four contributions. First, in the change literature there are two dominant theories: "The punctuated equilibrium and the continuous models." This study demonstrates that servitization is much more of a continuous process than a punctuated equilibrium. It also shows that the continuous process is neither logical nor structured but emergent and intuitive in nature. While structure and frameworks might be appealing, these have to be created in a way that recognizes and allows for an emergent servitization journey and provides scope to respond to opportunities and challenges as they arise.

Second, the study provides empirical evidence to support a contingency view of the dominance and sequencing of the different process models of change across the change journey. The chronological sequence of steps shown in this study, including the back-and-forth sequences, contributes to the typologies of organizational change, particularly to the fourth process model, "the evolution process" (Van de Ven and Sun, 2011), by explaining at a micro-process level how change unfolds. This is the first study in the transition to services to demonstrate this micro-process of how change unfolds.

The service journey and its 12 stages and corresponding sequential steps contribute to the literature on the transition to service by explaining how incremental change takes place. The previous literature on servitization shows some steps in the transition to services. These are largely independent, discontinuous and sequential from one another (see Mont 2002; Oliva and Kallenberg, 2003; Davies, 2004; Davies et al., 2007; Gebauer et al., 2006; Neely et al., 2008; Kindström, 2010; Martinez et al., 2010; Salonen, 2011; Lim et al., 2012; Barnett et al., 2013; Marques et al., 2013; Bakas et al., 2013). This study contributes to the literature in the service field by presenting three actual service journeys.

Third, this longitudinal study on the evolution of service development is not explained by previous research. Our research is consistent, to a certain extent, with previous research on the incremental continuum of service development (Oliva and Kallengberg, 2003; Tukker, 2004; Gebauger, 2008) and the co-existence of different types of service across the service continuum (Kindström and Kowalkowski, 2015). Our study extends the research of Kindström and Kowalkowski (2015), Oliva and Kallengberg (2003), Tukker (2004) and Gebauger (2008) by providing a clearer explanation of the dynamics of service development in the long term. In the first three years the development of services followed an incremental evolution of basic to intermediate services. In subsequent years the development of services has followed two concurrent streams of service development - "the continuous evolution of the basic to intermediate services and the emergence of complex services". This study explains how the evolution of services took place in our case studies, what types of service 
development took place and when these took place. Our research particularly extends the research of Kindström and Kowalkowski' (2015) by further explaining when the coexistence of basic, intermediate and complex services occurs across the service continuum.

Finally, this study provides a mainstream engineering case and two other cases, namely, well-being and learning, looking at the role of technology in service delivery.

\section{Implications for practice}

This research contributes to the field by presenting, first, three actual service journeys and, second, seven stages of the service strategy model that organizations should consider when managing their service journeys. The description of the progression of facts and the reality of these stories differentiate this research from other service transformation, transitioning or servitization studies.

Our findings show that firms compete in the market with a variety of services, from basic to complex ones. This variety has important implications for the operationalization of service business models. Future research should be dedicated to the analyses of the service variety and its correspondent business models in the context of entire service journeys.

\section{Limitations}

In social constructionist studies such as this, there is always the question of scientific realism and its counter-defence based on sample size. From the design of this study, we broaden the sample size, not limiting it by numbers; we also explore the journeys at three different levels within the same firms to increase the construct validity of the findings. Moreover, the presentation of findings to two focus groups strengthens the reliability of the findings. Nonetheless, from a scientific perspective and the notion of reality, this study is still limited by its sample size.

\section{References}

Alvarez, R., Martins, M., Terra da Silva, M., 2015. Applying the maturity model concept to the servitization process of consumer durables companies in Brazil. Journal of Manufacturing Technology Management, 26 (8), 10861105.

Auguste, B.G., Harman, E.P., Pandit, V., 2006, The right service strategies for product companies. The McKinsey Quarterly, 1 (1), 41-51.

Baines, T., Lightfoot, H., Benedettini, O., Kay, J., 2009, The servitization of manufacturing. A review of literature and reflection on future challenges. Journal of Manufacturing Technology, 20 (5), 547-567.

Baines, T.S., Lightfoot, H., Benedettini, O., Whitney, D., Kay, J.M., 2010. The adoption of servitization strategies by UK-based manufacturers. Proceedings 
of the Institution of Mechanical Engineers, Part B: Journal of Engineering Manufacture, 224 (5), 815-829.

Baines, T., Lightfoot, H., Smart, P., 2011. Servitization within manufacturing: Exploring the provision of advanced services and their impact on vertical integration. Journal of Manufacturing Technology Management, 22 (7), 947954.

Baines, T., Lightfoot, H., Smart, P., Fletcher, S., 2013. Servitization of manufacture: Exploring the deployment and skills of people critical to the delivery of advanced services. Journal of Manufacturing Technology Management, 24 (4), 637-646.

Baines, T., Lightfoot, H., 2013. Made to Serve: How Manufacturers can Compete Through Servitization and Product-Service Systems. Wiley, Hoboken, NJ, Chichester.

Baines, T., Lightfoot, H., Smart, P., Fletcher, S., 2014. Servitization of the manufacturing firm: Exploring the operations practices and technologies that deliver advanced services. International Journal of Operations and Production Management, 34 (1), 2-35.

Baines, T, Bigdeli, A.Z., Bustinza, O.F., Shi, V.G., Baldwin, J., Ridgway, K., 2016. Servitization: Revisiting the state of the art and research priorities, International Journal of Operations and Production Management, forthcoming.

Bakås, O., Powell, D., Resta, B., Gaiardelli, P., 2013. The servitization of manufacturing: A methodology for the development of after-sales services. Advances in Production Management Systems. Competitive Manufacturing for Innovative Products and Services IFIP Advances in Information and Communication Technology, 398 (PART 2), 337-344.

Barnett, N.J., Parry, G., Saad, M., Newnes, L.B., Goh, Y.M., 2013. Servitization is a paradigm shift in the business model and service enterprise required? Strategic Change, 22, 145-156.

Biege, S., Lay, G., Buschak, D., 2012. Mapping service processes in manufacturing companies: Industrial service blueprinting. International Journal of Operations and Production Management, 32, 932-57.

Bintner M.J., Ostrom A.L., Morgan F.B., 2008. Service blueprinting: A practical technique for service innovation. California Management Review, 50 (3), 66-94.

Bolton, R.N., Grewal, D., Levy, M., 2007. Six strategies for competing through service: An agenda for future research. Journal of Retailing, 83 (1), 1-4.

Bowen, D.E., Siehl, C., Schneider, B., 1989. A framework for analysing customer orientations in manufacturing. Academy of Management Review, $14,75-95$. 
Bowen, D.E., Schneider, B., 2014. A service climate synthesis and future research agenda. Journal of Service Research, 17, 5-22.

Breitbach C.F., Maglio P.P., 2016. Technology-enabled value co-creation: An empirical analysis of actors, resources, and practices. Industrial Marketing Management, 56, 73-85.

Brown, S., Eisenhardt, K., (1997). The art of continuous change: Linking complexity theory and time paced evolution in relentlessly shifting organizations. Administrative Science Quarterly, 42 (1) 1-34.

Chesbrough, H., 2010. Business model innovation: Opportunities and barriers. Long Range Planning, 43, 354-363.

Cusumano, M.A., Kahl, S.J., Suarez, F.F., 2015. Services, industry evolution, and the competitive strategies of product firms. Strategic Management Journal, 36, 559-575.

Davies, A., Brady, T., Hobday, M., 2007. Organizing for solutions: Systems seller vs. systems integrator. Industrial Marketing Management, 36,183-93.

Davies, S., 2004. Moving Base into High-value Integrated solutions: A Value Stream Approach. Industrial and Corporate Change, 13 (5), 727-756.

Dos Santos, J., Spector, B., Van Der Heyden, L., 2015. Towards a theory of business model change. In: N. Foss, T. Saebi, Business Model Innovation: The Organizational Dimension, Oxford University Press, Oxford.

Edmondson, A., McManus, S., 2007. Methodological fit in management field research. Academy of Management Review, 32 (4), 1155-1179.

Eloranta, V., Turunen, T., 2016. Platforms in service-driven manufacturing: Leveraging complexity by connecting, sharing and integrating. Industrial Marketing Management, 55, 178-186.

Fang, E.W., Palmatier, R.W., Steenkamp, J.B., 2008. Effect of Service Transition Strategies on Firm Value. Journal of Marketing, 72 (September), 114.

Gaiardelli, P., Resta, B., Martinez, V., Pinto, R., Albores, P., 2014. A classification model for product-service systems. Journal of Cleaner Production, 66, 507-519.

Gebauer, H., 2008. Identifying service strategies in product manufacturing companies by exploring environment-strategy configurations. Industrial Marketing Management, 37 (3), 278-291. 
Gebauer, H., Friedli, T., Fleisch, E., 2006. Success factors for achieving high service revenues in manufacturing companies. Benchmarking: An International Journal, 13 (3), 374-386.

Gebauer, H., Edvardsson, B., Bjurko, M., 2010. The impact of service orientation in corporate culture on business performance in manufacturing companies. Journal of Service Management, 21 (2), 237-259.

Gersick, G., 1994. Pacing strategic change: The case of a new venture. Academy of Management Journal, 37 (1) 9-45.

Hargrave, T.J., Van de Ven, A.H., 2006. A collective action model of institutional innovation. Academy of Management Review, 31 (4), 864-888.

Huy, Q.N., 2001. Time, temporal capability, and planned change. Academy of Management Review, 26 (4), 601-623.

Kindström, D., 2010. Towards a service-based business model - Key aspects for future competitive advantage. European Management Journal, 28 (6), 479-490.

Kindström, D., Kowalkowski, C., 2014. Service innovation in product-centric firms: A multidimensional business model perspective. Journal of Business and Industrial Marketing, 29, 96-111.

Kindström, D., Kowalkowski, C., 2015. Service-driven business model innovation: Organizing the shift from a product based to a service-centric business model. In: N. Foss, T. Saebi, Business Model Innovation: The Organizational Dimension, Oxford University Press, Oxford.

Kowalkowski, C., Windahl, C., Kindstrom, D., Gebauer, H., 2013. What service transition? Rethinking established assumptions about manufacturers service-led growth strategies. Industrial Marketing Management, 45, 59-69.

Langley, A., Smallman, C., Tsoukas, H., Van de Ven, A.H., 2013. Process studies of change in organization and management: Unveiling temporality, activity, and flow. Academy of Management Journal, 56, 1-13.

Li, J.H., Li, L., Chen, D.P., Ma, L.Y., 2015. An empirical study of servitization paradox in China. Journal of High Technology Management Research, 26 (1), 66-76.

Lim, C.-H., Kim, K.-J., Hong, Y.-S., Park, K. 2012. PSS Board: A structured tool for product-service system process visualization. Journal of Cleaner Production, 37, 42-53.

Loving, C., 2011. The IBM story. Book chapter in the Service Design and Delivery by Macintyre, M., Parry, G., Angelis, J., 31-40 ISBM 978-1-44198320-6. 
Malleret, V., 2006. Value Creation through Service Offers. European Management Journal, 24 (1), 106-116.

Marques, P., Cunha, P.F., Valente, F., Leitão, A., 2013. A Methodology for Product-service Systems Development. Procedia CIRP, 7, 371-376.

Martinez, V., Bastl, M., Kingston, J., Evans, S., 2010. Challenges in transforming manufacturing organisations into product service providers. Journal of Manufacturing Technology Management, 21 (4), 449-469.

Meyer-Glodsmith, S., Jonston, R., Duffy J., Rao J., 2002. The service concept: The missing link in service design research? Journal of Operations Management, 20 (2), 121-134.

Mont, O., 2002. Clarifying the concept of product-service system. Journal of Cleaner Production, 10 (3), 237-245.

Neely, A., 2008. Exploring the financial consequences of the servitization of manufacturing. Operations Management Research, 1 (2), 103-18.

Ng, I., Parry, G., Wild, P., McFarlane, D., Tasker, P., 2011. Complex Engineering Service Systems: Concepts and Research. London: SpringerVerlag.

Ng, I., Ding, D., Yip, N., 2013. Outcome-based contracts as new business model: The role of partnership and value-driven relational assets. Industrial Marketing Management, 42 (5), 730-743.

Oliva, R., Kallenberg, R., 2003. Managing the transition from products to services. International Journal of Service Industry Management, 14, 160-72.

Paiola, M., Saccani, N., Perona, M., Gebauer, H., 2013. Moving from products to solutions: Strategic approaches for developing capabilities. European Management Journal, 31, 390-409.

Parry, G., Vendrell-Herrero, F., Bustinza, O., 2014. Using data in decisionmaking: Analysis from the music industry. Strategic Change, 23 (3/4) 265277.

Quinn, J.B., Doorley, T.L., Paquette, P.C., 1990. Beyond products: Servicebased strategies. Harvard Business Review, March-April.

Raddats, C., Baines, T., Burton, J., Story, V., Zolkiewski, J., 2016. Motivations for servitization: The impact of product complexity. International Journal of Operations and Production Management, 36 (5), 572-591.

Rasmussen, K., Foss, N., 2015. Business model innovation in the pharmaceutical industry: The supporting role of organizational design. In: N. Foss, T. Saebi, Business Model Innovation: The Organizational Dimension, Oxford University Press, Oxford. 
Reinartz, W., Ulaga, W., 2008. How to sell services more profitably. Harvard Business Review, 86 (5), 90-96.

Roy, R., Shehab, E., Tiwari, A., Rexfelt, O., Hiort Af Ornäs, V., 2009. Consumer acceptance of product-service systems: Designing for relative advantages and uncertainty reductions. Journal of Manufacturing Technology Management, 20, 674-99.

Salonen, A., 2011. Service transition strategies of industrial manufacturers. Industrial Marketing Management, 40 (5), 683-690.

Settanni, E., Newnes, L.B., Thenent, N.E., Parry, G., Goh, Y.M., 2014. A through-life costing methodology for use in product-service-systems. International Journal of Production Economics, 153, 161-77.

Smith, D.J., 2013. Power-by-the-hour: The role of technology in reshaping business strategy at Rolls-Royce. Technology Analysis and Strategic Management, 25, 987-1007.

Smith, L., Maull, R., Ng, I., 2014. Servitization and Operations Management: A Service-Dominant Logic Approach. International Journal of Operations \& Production Management, 34 (2), 242-269.

Spring, M., Araujo, L., 2009. Service, services and products: Rethinking operations strategy. International Journal of Operations \& Production Management, 29 (5), 444-467.

Starbuck, W. H., Hedberg, B., 2015. How organisations learn from success and failure. Working paper series SSRN 2708267.

Story, V.M., Raddats, C., Burton, J., Zolkiewski, J., Baines, T. 2016. Capabilities for advanced services: A multi-actor perspective. Industrial Marketing Management. In Press.

Tukker, A., 2004. Eight types of product-service system; eight ways to sustainability? Experiences from suspronet. Business strategy and the environment, 13, 246-260.

Tushman, M., Anderson, P., 1986. Technological discontinuities and organizational environments. Administrative Science Quarterly, 31(3) 439465.

Vandermerwe, S., Rada, J., 1988. Servitization of business: Adding value by adding services. European Management Journal, 6,314-324.

Van de Ven, S., Poole, M.S., 1995. Explaining development and change in organizations. Academy of Management Review, 20(3) 510-540. 
Van de Ven, S., Sun, K., 2011. Breakdowns in implementing models of organizational change. Academy of Management Perspectives, 25 (3) 58-74.

Vargo, S.L., Lusch, R.F., 2007. From goods to service(s): Divergences and convergences of logics. Industrial Marketing Management, 37, 254-259.

Vargo, S., Maglio P., Akaka M., 2008. On value and value co-creation: A service systems and service logic perspective. European Management Journal, 26, 145-152.

Vendrell-Herrero, F., Parry, G., Bustinza, O.F., O'Regan, N., 2014. Servitization as a driver for organizational change. Strategic Change, 23 (56), 279-285.

Visnjic, I., Val Looy, B., 2013. Servitization: Disentangling the impact of service business model innovation on manufacturing firm performance. Journal of Operations Management, 31 (4), 169-180.

Visnjic, I., Wiengarten, F., Neely, A., 2013. Steering manufacturing firms towards service business model innovation. California Management Review, 56 (1), 100-123.

Visnjic, I., Wiengarten, F., Neely A., 2016. Only the brave: Product innovation, service business model innovation, and their impact on performance. Journal of Product Innovation Management, 33 (1), 36-52.

Weick, K.E., Quinn, R.E., 1999. Organizational change and development. Annual Review of Psychology, 50, 361-386.

Wise, R., Baumgartner, P., 1999. Go downstream: The new profit imperative in manufacturing. Harvard Business Review, 77, 133-141. 
Martinez V., Neely A., Velu C, Leinster-Evans S. and Bisessar D. (2017); "Exploring the journey to services". Special issue in "Service Implementation on Manufacturing firms: Strategy, Economics and Practice". International Journal of Production Economics. (Accepted)

Figure 1. The service journey: cross-case comparison

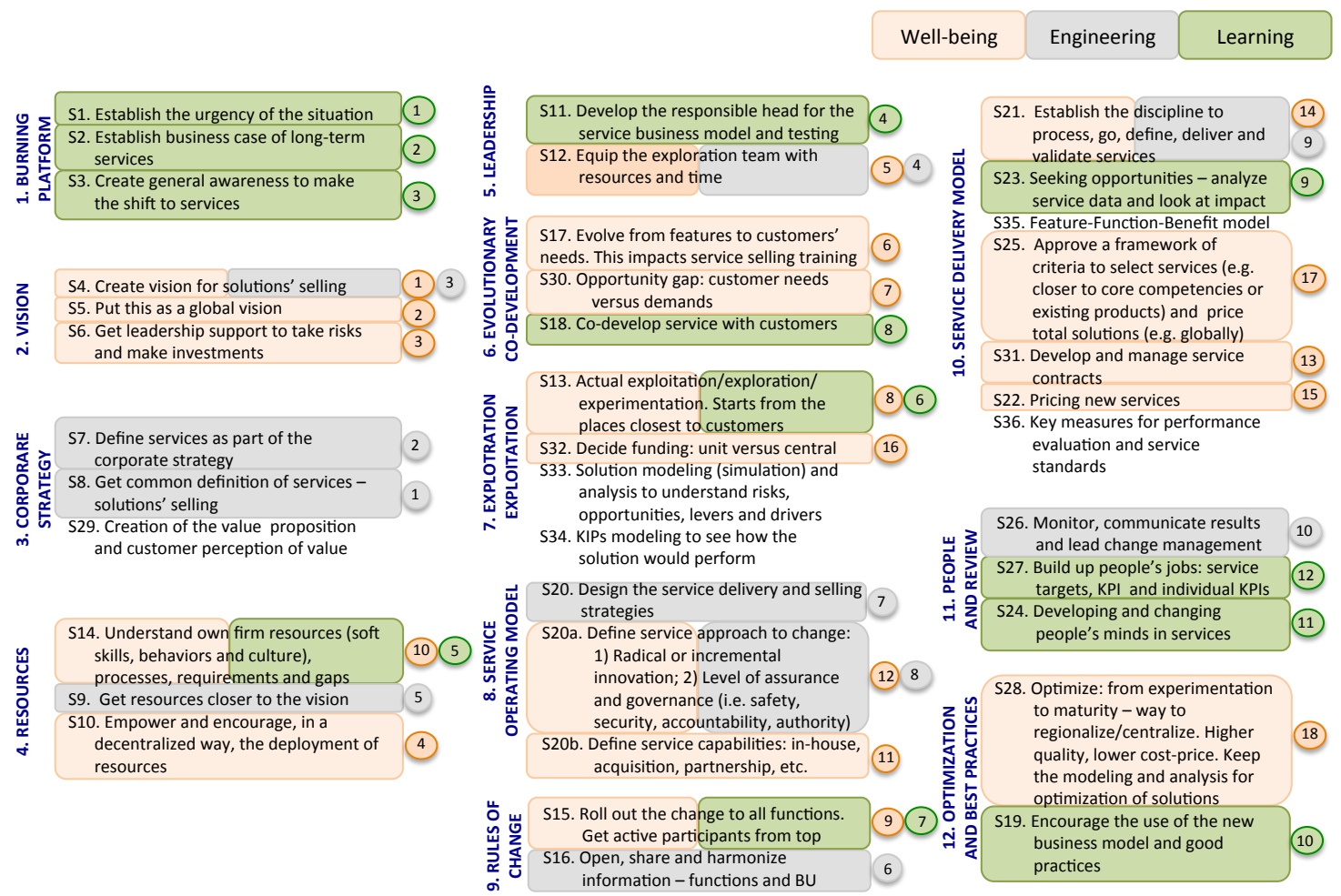

Note: Individual firms' service journeys are colour-coded and the sequences of the journeys' steps are numbered on the right-hand side of the colour-coded activity. 
Figure 2. Service strategy model

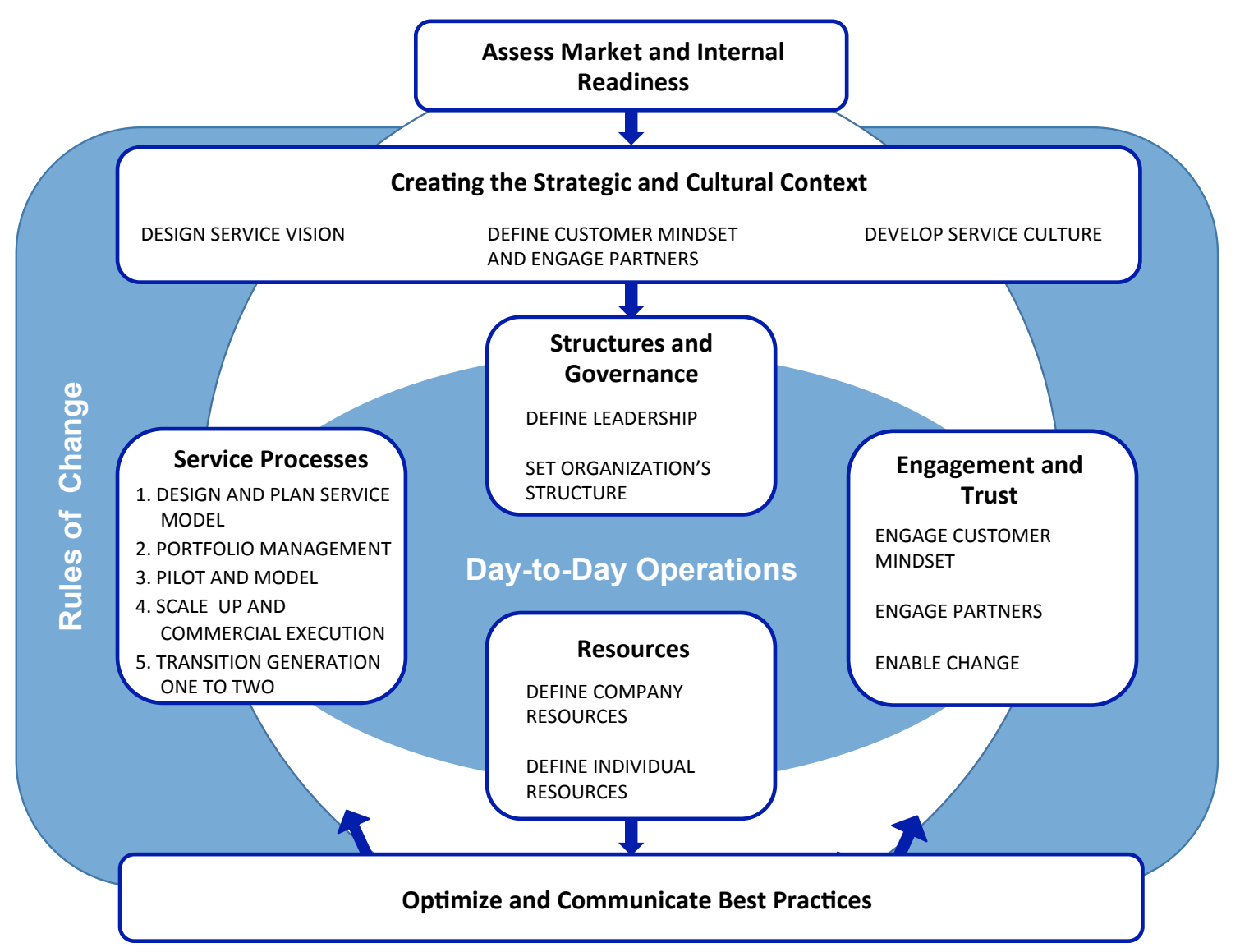

